Egyptian Journal of Aquatic Biology \& Fisheries

Zoology Department, Faculty of Science,

Ain Shams University, Cairo, Egypt.

ISSN $1110-6131$

Vol. 23(4): $659-666$ (2019)

www.ejabf.journals.ekb.eg

\title{
Chemical composition and water quality of some rivers of the sverdlovsk oblast (Ural, Russia)
}

\author{
Flefel, H. E. ${ }^{1,2^{*}}$; Nokhrin, D. Yu. ${ }^{3}$ and Donnik, I. M. ${ }^{1}$ \\ 1- Ural State Agrarian University (620075, Yekaterinburg, Karl Liebknecht st., 42, \\ Russia). \\ 2- Department of Environmental Research and Medical Malacology, Theodor Bilharz \\ Research Institute, Egypt. \\ 3- Federal State Budgetary Scientific Institution «Ural Federal Agrarian Scientific \\ Research Centre, Ural Branch of Russian Academy of Sciences». \\ *Corresponding author: hflefel@hotmail.com
}

\author{
ARTICLE INFO \\ Article History: \\ Received: Aug. 25, 2019 \\ Accepted: Oct. 27, 2019 \\ Online: Nov. 2019

\section{Keywords:} \\ Sverdlovsk oblast \\ Ural \\ Rissia \\ Chemical composition \\ water quality \\ Heavy metals \\ Biogenic compounds
}

\begin{abstract}
The water quality of a river is very important as it is using for drinking and domestic purposes, agriculture and aquatic life including fish and fish farming. The concentration of the major ions $\left(\mathrm{Cl}^{-}, \mathrm{SO}_{4}{ }^{2-}, \mathrm{K}^{+}, \mathrm{Na}^{+}, \mathrm{Mg}^{2+}\right.$, $\left.\mathrm{Ca}^{2+}\right)$, nitrogen and phosphorus compounds $\left(\mathrm{NH}_{4}^{+}, \mathrm{NO}_{2}^{-}, \mathrm{NO}_{3}^{-}, \mathrm{HPO}_{4}{ }^{2-}\right)$, ions $\mathrm{Ba}^{2+}, \mathrm{Sr}^{2+}$, Heavy metals and trace elements $\left(\mathrm{Ba}^{2+}, \mathrm{Fe}, \mathrm{Cd}, \mathrm{Co}, \mathrm{Si}, \mathrm{Mn}\right.$, $\left.\mathrm{Cu}, \mathrm{Ni}, \mathrm{Pb}, \mathrm{Sr}^{2+}, \mathrm{F}, \mathrm{Zn}\right)$, concentration was determined. The results showed that general indicators, according to the chromaticity value, samples of different rivers differed very strongly. According to the value of mineralization, the water of all samples was fresh. According to the cationic composition, 7 samples had calcium type and one (Pozarishka) had a mixed type. Also, the content of organic matter in the samples was generally significant. The lowest oxidation values were recorded in the samples of the Ufa river network (Nos. 6 and 7), The highest in the water of Iset river. The concentration of most elements in the water exceeded the standard values.
\end{abstract}

\section{INTRODUCTION}

The goal of water conservation in every country is to be achieved by strengthening watercare, which often means monitoring water quality. Chemical analysis and determination of tracing of heavy metals such as lead, cadmium, iron, copper, etc. are of great importance. Heavy metals include a number of physiologically important elements in their low levels, such as $\mathrm{Cu}, \mathrm{Fe}, \mathrm{Zn}$; highly toxic like $\mathrm{Pb}, \mathrm{Mn}, \mathrm{Cd}, \mathrm{Hg}$, $\mathrm{As}, \mathrm{Sb}$ and less toxic like $\mathrm{Au}, \mathrm{Ag}$, and $\mathrm{Cr}$, etc (Odobasic 2012).

In water, heavy metals quickly decompose and settle in the form of soluble solid carbon, sulphates, and sulfides at the bottom. At that time, when the absorption capacity of the precipitate is exhausted, the concentration of metal ions in water increases (Biki 2016).

Water has become an important goods for the evolvement of industrial and agriculture. Water is completely not only important for the survival of human beings but also animals, plants and all other living things. (Palevitz 1999). Also, water is extremely important for the quality of life. Oceans, rivers, lakes, and streams together 
with the earth form the strengths on which life grows and react.. balance of environmental kept by the amount and water quality control the way of life of a people.. On the other hand, contaminated water is a huge source of disease, and, in addition to spoiling the earth, it also becomes unsuitable for life. (Siebe 1994).

Quality of water is a growing global challenge. Polluted water and poor sanitation are killing many children around the world every day. Quality of water is the physic-chemical and biological properties of water in relation to many of standards. The main uses considered for this feature are parameters that relate to drinking water, human contact safety, and ecosystem health. Interest in water analysis is associated with the tremendous importance of water for all categories of living things. It is necessary for the healthy development of humans, animals, and plants.

Water quality depends on the ion that dissolves in water. The main ions that are responsible for maintaining water quality are carbonate, bicarbonate, chloride, sulfate, nitrate, and fluorine. These ions are present in anionic form. Cation and anions must be equal in order to maintain water quality. Cations are also present in water in the form of hardness and salinity. Natural qualities of water are subject to destruction as a result of human activity. Municipal and industrial waters entering the water are the main source of organic and inorganic contaminants. (Kafia et al., 2011). The chemical subject of water quality has become a cause of growing concern, as chemicals contaminated the environment in industrial effluents pose a great risk to humans, animals, and plants (Lou et al., 2007).

The water quality may to give a detailed about of the concentration and state the organic and inorganic matter present in the water, together with certain physical characteristics of the water. the surface water composition is influenced by natural factors in the drainage basin and varies with seasonal differences in runoff volumes, weather conditions, and water levels (Mapfumo et al., 2002). The purpose of the study is to assess water quality, the chemical composition, and determination of some heavy metals in some rivers of the Urals.

\section{MATERIALS AND METHODS}

\section{Study area and sampling}

Water sampling was carried out in the winter of 2017 from the surface of Sverdlovsk oblast's 8 rivers (Russian Federation). The sampling locations are presented in Table 1 and Fig. 1.

Table 1: Sampling sites on the rivers of the Sverdlovsk oblast in 2017

\begin{tabular}{cll}
\hline № & \multicolumn{1}{c}{ River } & \multicolumn{1}{c}{ Location } \\
\hline 1 & Pozarishka & Kamensky district, Pozarishka village \\
2 & Brusyanka & Beloyarsky district, Studencheskij village \\
3 & Iset & Yekaterinburg city \\
4 & Baltym & Verkhnyaya Pyshma city, Sadovij village \\
5 & Pychma & Sukholozhsky district, Kuryi village \\
6 & Manchazh & Artinsky district, Manchazh village \\
7 & Ufa & Krasnoufimsky district, Kljuchiki village \\
8 & Tura & Nizhneturinsky district, Nizhnyaya Tura \\
\hline
\end{tabular}

\section{Sample preparation and analysis}

In winter, eight surface water samples were taken, as well as from areas adjacent to the agricultural sector located near settlements, using $1000 \mathrm{ml}$ polyethylene terephthalate (PET) bottles. All PET bottles were rinsed with the surface water of each area before sampling, and samples were taken $100 \mathrm{~mm}$ below the level 
of surface water, away from the edge of each surface river. Samples were appropriately labeled for on-site identification and immediately delivered to the laboratory immediately after sampling for storage and analysis.

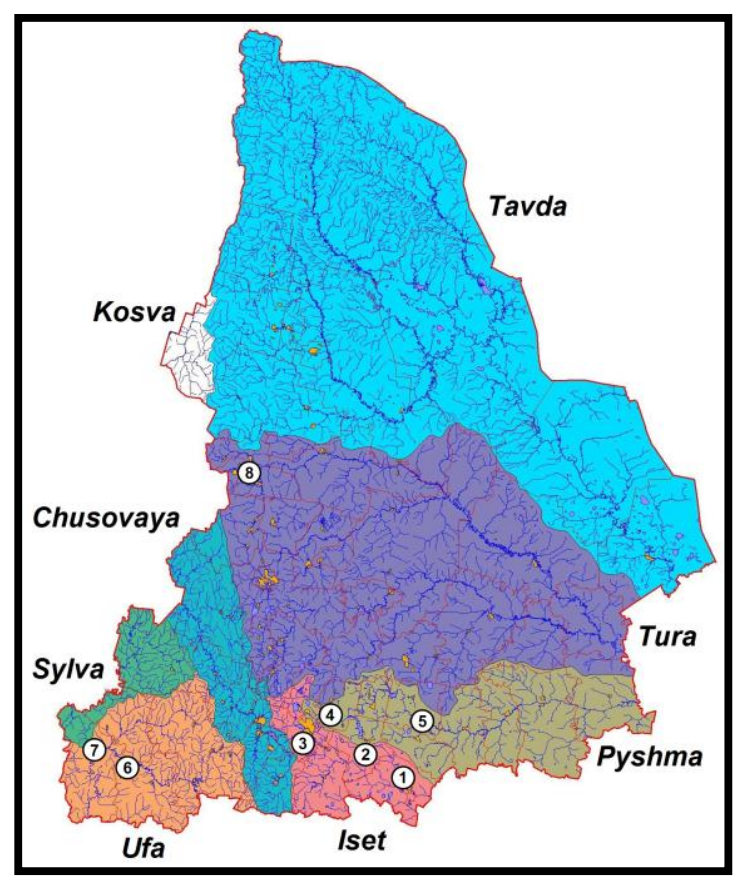

Fig. 1: Sampling locations on the map of the river basins of the Sverdlovsk oblast.

The storage time for the water samples was seven days at $4{ }^{\circ} \mathrm{C}$ (in the refrigerator) by adding $\mathrm{HNO}_{3}$ to maintain a pH of $<2$ in accordance with the guidelines for industrial waste resources (EPA and Victoria 2009).

The concentration of the major ions $\left(\mathrm{Cl}^{-}, \mathrm{SO}_{4}{ }^{2-}, \mathrm{K}^{+}, \mathrm{Na}^{+}, \mathrm{Mg}^{2+}, \mathrm{Ca}^{2+}\right)$, nitrogen and phosphorus compounds $\left(\mathrm{NH}_{4}^{+}, \mathrm{NO}_{2}^{-}, \mathrm{NO}_{3}^{-}, \mathrm{HPO}_{4}{ }^{2-}\right)$, and ions $\mathrm{Ba}^{2+}, \mathrm{Sr}^{2+}$ was determined by capillary electrophoresis ("Capel-103R", Lumex®, St. Petersburg, Russia).

The data collection was obtained using electropherograms' analysis and calculations with calibration curves were performed in the package "Multichrom for Windows" (version 1.52u, Ampersand Ltd, Moscow, Russia). The total alkalinity, the content of bicarbonate and carbonate ions were calculated by the inflection point of the titration curve for $30 \mathrm{~mL}$ of the sample with a $0.02 \mathrm{~mL} \mathrm{HCl}$. The calculations were performed in the Alkalinity calculator software (version 2.22) (Rounds 2013).

Photometric measurements were taken using a CFC-2 concentration photoelectric colorimeter (OJSC "Zagorsk Optical-Mechanical Plant", Sergiev Posad, Russia), potentiometric measurements were performed on I-160 MI ion meter (LLC "Measuring technique", Moscow, Russia), and conductometric on conductometer EZ1 (Meterics ${ }^{\circledR}$, China).

\section{Heavy metals}

The analysis of the metal content in water was carried out after preliminary filtration on the atomic absorption spectrometer MGA-915MD (Lumex®, St. Petersburg, Russia). As calibration solutions the mixtures of state standard reference samples of individual ions were used.

\section{Statistical Analysis}

To build the Piper chart, we used the package GW_Chart (version 1.29), a new version of the MODFLOW Graphical User Interface for Argus ONE (MODFLOW 
GUI) that adds support for the U.S. Geological Survey's MODFLOW-2000 and the Reservoir, Transient Leakage, Interbed Storage, Lake, and Gage packages. MODFLOW is a groundwater modeling program. It can be compiled and remedied according to the practical applications. Because of its structure and fixed data format, MODFLOW can be integrated with Geographic Information Systems (GIS) technology for water resource management. The new version can also import existing MODFLOW-88 and MODFLOW-96 models. A utility program, GW_Chart, was developed in conjunction with the MODFLOW GUI and is used for post-processing of the output of MODFLOW (Winston 2000). For the exploratory data analysis, the Principal Coordinates Analysis (PCoA) technique was used in the package PAST (version 3.24) (Hammer et al., 1999).

\section{RESULTS AND DISCUSSION}

The results of the analysis are presented in Table 2 .

Table 2: Chemical composition of water in some Sverdlovsk oblast rivers (excess standards for fisheries in bold)

\begin{tabular}{|c|c|c|c|c|c|c|c|c|c|}
\hline № & Indicators & 1 & 2 & 3 & 4 & 5 & 6 & 7 & 8 \\
\hline \multicolumn{10}{|c|}{ General indicators } \\
\hline 1 & Alkalinity, mg/L & 5.22 & 3.30 & 1.52 & 2.37 & 2.00 & 5.15 & 2.95 & 1.32 \\
\hline 2 & $\begin{array}{l}\text { Chromaticity, } \\
{ }^{\circ} \text { chrome-cobalt scale }\end{array}$ & 57.5 & 31.4 & 25.4 & 17.9 & 25.1 & 4.5 & 7.8 & 33.1 \\
\hline 3 & Conductivity, $\mu \mathrm{S} / \mathrm{cm}$ & 928 & 393 & 385 & 332 & 396 & 544 & 312 & 250 \\
\hline \multirow[t]{3}{*}{4} & Mineralization, mg/L & & & & & & & & \\
\hline & - Residue at $180^{\circ} \mathrm{C}$ & 509 & 227 & 138 & 148 & 272 & 335 & 192 & 115 \\
\hline & - Total dissolved solids & 839 & 357 & 279 & 284 & 337 & 535 & 292 & 191 \\
\hline 5 & $\mathrm{pH}$, scale & 7.13 & 7.28 & 6.80 & 7.09 & 7.66 & 7.18 & 8.00 & 7.99 \\
\hline 6 & Total hardness, mg/L & 8.99 & 3.86 & 3.24 & 3.27 & 3.87 & 6.03 & 3.53 & 2.41 \\
\hline \multicolumn{10}{|c|}{ Major ions and carbonate system, $\mathrm{mg} / \mathrm{L}$} \\
\hline 7 & Bicarbonate $\left(\mathrm{HCO}_{3}^{-}\right)$ & 318.4 & 201.3 & 92.7 & 144.6 & 122.0 & 314.2 & 180.0 & 80.5 \\
\hline 8 & Potassium $\left(\mathrm{K}^{+}\right)$ & 11.9 & 2.3 & 2.0 & 5.2 & 4.8 & 1.6 & 1.6 & .9 \\
\hline 9 & Calcium $\left(\mathrm{Ca}^{2+}\right)$ & 103.2 & 57.5 & 44.1 & 47.4 & 50.3 & 99.6 & 56.4 & 35.5 \\
\hline 10 & Carbonate $\left(\mathrm{CO}_{3}{ }^{2-}\right)$ & .27 & .21 & .03 & .09 & .31 & .27 & .96 & .41 \\
\hline 11 & Magnesium $\left(\mathrm{Mg}^{2+}\right)$ & 46.7 & 12.0 & 12.6 & 11.0 & 16.5 & 12.9 & 8.7 & 7.8 \\
\hline 12 & Sodium $\left(\mathrm{Na}^{+}\right)$ & 65.3 & 13.7 & 13.2 & 9.8 & 18.2 & 8.9 & 6.9 & 5.7 \\
\hline 13 & Sulphate $\left(\mathrm{SO}_{4}{ }^{2-}\right)$ & 218.4 & 32.8 & 75.2 & 33.0 & 87.7 & 49.1 & 25.5 & 46.1 \\
\hline 14 & Chloride $\left(\mathrm{Cl}^{-}\right)$ & 63.4 & 20.7 & 29.1 & 26.1 & 31.9 & 11.8 & 8.4 & 8.3 \\
\hline \multicolumn{10}{|c|}{ Biogenic compounds, $\mathrm{mg} / \mathrm{L}$ and organic matter } \\
\hline $15^{\circ}$ & Ammonium $\left(\mathrm{NH}_{4}^{+}\right)$ & .41 & .18 & .46 & .28 & .10 & .14 & .03 & .15 \\
\hline 16 & Nitrate $\left(\mathrm{NO}_{3}{ }^{-}\right)$ & 2.23 & 11.3 & 4.44 & 1.84 & 2.86 & 24.1 & 1.49 & .58 \\
\hline 17 & Nitrite $\left(\mathrm{NO}_{2}^{-}\right)$ & 2.04 & .16 & 1.10 & .15 & 1.06 & .38 & .16 & 2.24 \\
\hline 18 & Phosphate $\left(\mathrm{HPO}_{4}{ }^{2-}\right)$ & .43 & .20 & .14 & .02 & .27 & .53 & .23 & .25 \\
\hline 19 & Permanganate oxidability, $\mathrm{mgO} / \mathrm{L}$ & 5.09 & 5.52 & 7.49 & 5.62 & 5.17 & 1.47 & 2.06 & 7.44 \\
\hline \multicolumn{10}{|c|}{ Heavy metals and trace elements, $\mathrm{mg} / \mathrm{L}$} \\
\hline 20 & Barium $\left(\mathrm{Ba}^{2+}\right)$ & 1.84 & .44 & .13 & .21 & .09 & 2.11 & .34 & .15 \\
\hline 21 & Iron $(\mathrm{Fe})$ & .029 & .045 & .097 & .064 & .029 & .045 & .037 & 1.91 \\
\hline 22 & Cadmium $(\mathrm{Cd})$ & .0063 & .0047 & .0031 & .0047 & .0015 & .0015 & .0047 & .0015 \\
\hline 23 & Cobalt (Co) & .317 & .121 & .138 & .105 & .061 & .043 & .036 & .024 \\
\hline 24 & Silicon $(\mathrm{Si})$ & 3.64 & 4.25 & 2.71 & 4.07 & .66 & 5.44 & .46 & 1.41 \\
\hline 25 & Manganese (Mn) & .019 & .016 & .013 & .013 & .013 & .013 & .019 & .019 \\
\hline 26 & Copper $(\mathrm{Cu})$ & .012 & .010 & .006 & .008 & .003 & .003 & .002 & .003 \\
\hline 27 & Nickel (Ni) & .103 & .086 & .035 & .086 & .052 & .069 & .035 & .035 \\
\hline 28 & Lead $(\mathrm{Pb})$ & .106 & .083 & .062 & .083 & .083 & .106 & .133 & .083 \\
\hline 29 & Strontium $\left(\mathrm{Sr}^{2+}\right)$ & .67 & .25 & .28 & .20 & .08 & 4.60 & .58 & .16 \\
\hline 30 & Fluorine $\left(\mathrm{F}^{-}\right)$ & .15 & .14 & .45 & .10 & .16 & .14 & .10 & .08 \\
\hline 31 & Zinc (Zn) & .057 & .187 & .063 & .084 & .084 & .107 & .106 & .084 \\
\hline
\end{tabular}




\section{General indicators}

According to the chromaticity value, samples of different rivers differed very strongly: from 1.52 in the Iset River to 57.5 in the Pozarishka River. The water of 5 rivers had a neutral reaction, 3-slightly alkaline. According to the value of mineralization, the water of all samples was fresh $(<1000 \mathrm{mg} / \mathrm{L})$. The water of most (6) samples was soft $(<4 \mathrm{mg} / \mathrm{L})$, in Manchazh river had medium hardness $(4-8 \mathrm{mg} / \mathrm{L})$ and in Pozarishka river had high hardness.

\section{Major ions}

The ratios of principal ions equivalent concentrations are presented in Fig. 2. According to the cationic composition, 7 samples had calcium type and one (Pozarishka) had a mixed type due to a slightly higher proportion of sodium and magnesium. On the cation's ternary plot all the samples formed a line, which indicates cation's similarity of the sources in the waters of the studied rivers. According to the anionic composition, 5 samples had a bicarbonate type and 3 samples had mixed sulphate-bicarbonate. On the anion field of the graph, the samples formed two clusters differing in the relative proportion of sulfate ions. In general, the presence of one cationic and two anionic trends should be interpreted as the source of the main ions' origin in the studied rivers is the leaching of calcium and magnesium carbonates from carbonate sediments: limestone, dolomite and anhydrite (Olkowska et al., 2017). It can be assumed that the role of anhydrites in the formation of the anionic composition of the Pozarishka, Iset, Pyshma and Tura rivers is higher.

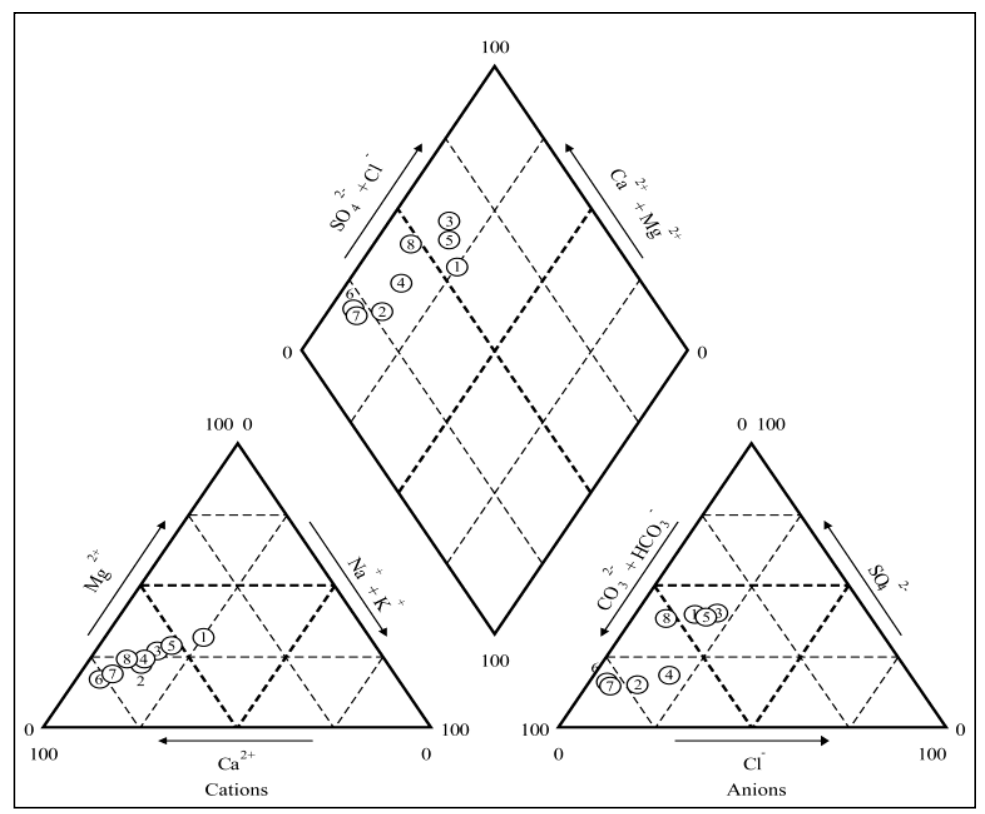

Fig. 2: Piper diagram of water samples in the study area

\section{Biogenic compounds and organic matter}

The content of organic matter in the samples was generally significant. The lowest oxidation values were recorded in the samples of the Ufa river network (Nos. 6 and 7), The highest in the water of Iset River. Total ammonia (TAN), in particular, the union compound, is one of the main environmental pollutants in freshwater systems that are physiologically harmful to aquatic organisms and affect the functionality of ecosystems (Leoni et al., 2018). Ammonium concentrations were low, indicating a lack of fresh organic water pollution. However, in all the samples the concentration of nitrate was increased. Nitrites are the last part of the oxidation of organic nitrogen in 
the chain: ammonium - nitrite - nitrate. Therefore, the presence of nitrite should be interpreted as the incompleteness of the nitrogen oxidation processes as a result of oxygen deficiency (Olkowska et al., 2017; Leoni et al., 2018). Since the sampling was carried out in winter, when the rivers are covered with ice, the lack of oxygen is natural. Thus, elevated nitrate concentrations should be considered as a seasonal phenomenon, not associated with anthropogenic impact. The concentration of phosphates in most samples exceeded the standards for eutrophic water bodies $(0.2$ $\mathrm{mg} / \mathrm{L}$ ), but not too high.

\section{Heavy metals and trace elements}

The concentration of most elements in the water exceeded the standard values. It should be noted that in the Russian Federation the standards for the quality of natural waters for trace elements are quite strict because they imply the use of waters for the fishery. Elevated relative to the standards, the concentration of elements is usually for the Ural region and is associated with the peculiarities of the geochemical background. It is dominated by natural-man-made biogeochemical provinces in places of natural mineral deposits (brown coal, peat, metals, sand, clay, stones, and minerals) and industrial enterprises associated with them for their extraction and processing. Thus, the observed state is fairly common to the studied area's waters(Bobrova 2016).

In an attempt to identify possible patterns of microelements, we applied a multivariable PCoA technique. Its results are interpreted similarly to the analysis of PCA; however, not only the Pearson correlation, but also other similarity measures can be used, and we used the non-parametric Spearman correlation. The results of the analysis are presented in the ordination diagram (Fig. 3).

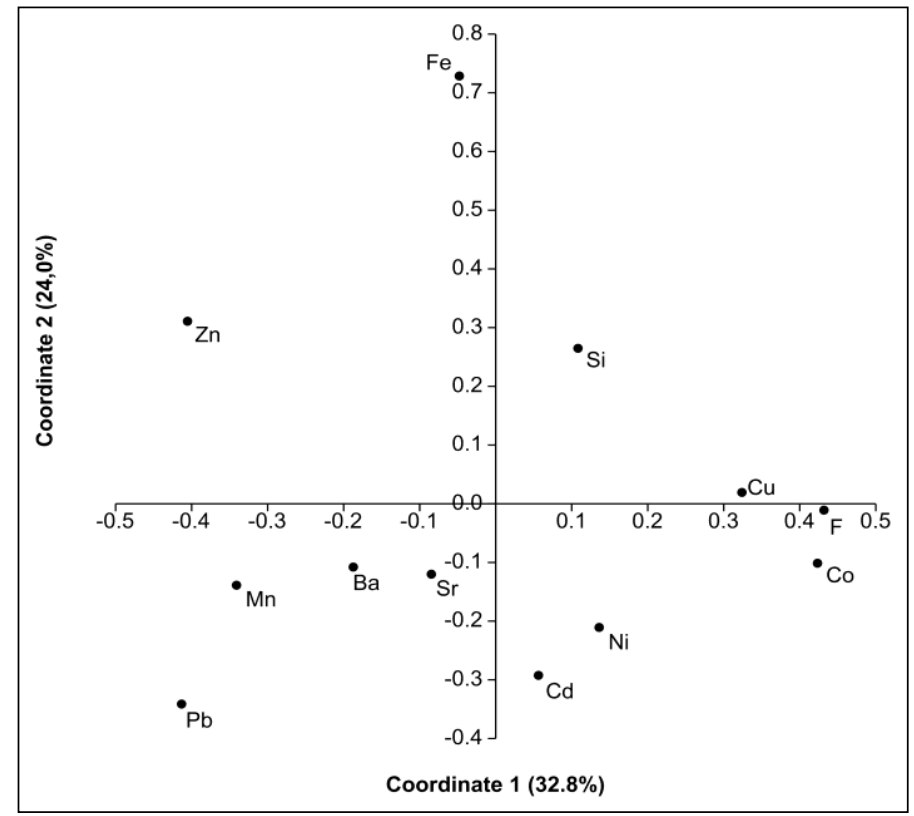

Fig. 3: Heavy metals and trace elements in the space of the first two principal coordinates of the metric scaling analysis (similarity - Spearman's Rho).

It can be seen that the first two axes explained more than $50 \%$ of the data's variability, with the first axis being about a third. With the greatest positive loadings, it included F, Co, $\mathrm{Cu}$, and with the smallest - Pb, $\mathrm{Zn}, \mathrm{Mn}$. Despite the small sample, the pattern of elements on the right side of the diagram is well interpreted. Cobalt, nickel, chromium and copper in the Urals are often in association, as they have a common origin, namely, the ultrabasic hyperbasites (ultrabasites) of the Ural 
mountains. As a result of the weathering processes, rocks are destroyed and this group of elements is consistently present in soils, as well as in bottom sediments and water of water bodies. The presence of fluorine in this pattern is also explicable. It is known that, unlike most other ultrabasites, which usually contain $20 \mathrm{mg} / \mathrm{kg}$ of fluorine, the Urals ultrabasic contains an average of $590 \mathrm{mg} / \mathrm{kg}$ (up to $1300 \mathrm{mg} / \mathrm{kg}$ ) of fluorine (Yanin 2007). As can be seen from table 2, the highest concentrations of $\mathrm{Co}, \mathrm{F}$ and $\mathrm{Cu}$ were noted in samples 1,2 and 3. Thus, the results of PCoA indicate that the formation of the trace element composition of the Iset river basin's waters is significantly influenced by the natural weathering processes of the Ural ultrabasites.

For coordinate 2, the largest multidirectional loadings gave $\mathrm{Fe} v \mathrm{~Pb}, \mathrm{Cd}$. This pattern is interpreted worse. It can only be noted that $\mathrm{Pb}$ and $\mathrm{Cd}$ can have a technogenic origin, and the variability of iron is most likely due to natural causes.

\section{CONCLUSION}

The concentration of most elements in the water exceeded the standard values. It should be noted that in the Russian Federation the standards for the quality of natural waters for trace elements are quite strict since they imply the use of water for fishing. Elevated concentration of elements relative to standards is usually for the Ural region and is associated with the peculiarities of the geochemical background. Also, the content of organic matter in the samples was generally significant, ammonium concentrations were low, indicating a lack of fresh organic water pollution. Mining and minerals activities in the Urals region have a negative impact on water bodies in terms of increased pollution, which affects water quality, characteristics and components.

\section{REFERENCES}

Biki, F. (2016). "Preliminary Analysis of Heavy Metals Content in the River Bosna Upstream and Downstream from the Industrial Plants in Zenica and Pollution B ulletin of the Chemists and Technologists of Bosnia and Herzegovi N," no. January 2013.

Bobrova, Z. M. (2016). "Impact of Enterprises of Ural Mineral Resource Complex on Water Resources" i (41): 67-71.

EPA, and Victoria.( 2009). "Industrial Waste Resource Guidlines Sampling and Analysis of Waters, Wastewaters, Soils and Wastes" 2009 (June): 1-36.

Hammer, Ø.; David, A. T. H. and Paul, D. R. (1999). "PAST: Paleontological Statistics Software Package." Palaeontologia Electronica 4 (1): 1-9. https://doi.org/10.1016/j.bcp.2008.05.025.

Kafia, M.S.; Slaiman, G.M. and Nazanin, M.S. (2011). "Physical and Chemical Status of Drinking Water from Water Treatment Plants on Greater Zab River.” J. Appl. Sci. Envir. Manag. 13 (3): https://doi.org/10.4314/jasem.v13i3.55371.

Leoni, B.;Martina P.; Valentina, S. and Veronica, N. (2018). "Ammonium Transformation in 14 Lakes along a Trophic Gradient." Water (Switzerland) 10 (3). https://doi.org/10.3390/w10030265.

Lou, J.; Lee, W. and Han, J. (2007). "Influence of Alkalinity, Hardness and Dissolved Solids on Drinking Water Taste: A Case Study of Consumer Satisfaction." J. Envir. Manag., 82 (1): 1-12. https://doi.org/10.1016/j.jenvman.2005.11.017.

Mapfumo, E.; Willms, W. D. and Chanasyk, D. S.( 2002). "Water Quality of Surface Runoff from Grazed Fescue Grassland Watersheds in Alberta.” Water Quality 
Research Journal of Canada 37 (3): 543-62. https://doi.org/10.2166/wqrj.2002.036. Odobasic, A. (2012). "Determination and Speciation of Trace Heavy Metals in Natural Water by DPASV." Water Quality Monitoring and Assessment. https://doi.org/10.5772/32339.

Olkowska, E.; Ruman, M.; Drąg-Śmigalska , M. and Polkowska, Ż. (2017). "Selected Anionic and Cationic Surface Active Agents: Case Study on the Kłodnica Sediments." Limnological Review 17 (1): 11-21. https://doi.org/10.1515/limre2017-0002.

Palevitz, B. A. (1999). “Ancient DNA - When Is Old Too Old?" Scientist 13 (15): 10.

Rounds, Stewart. 2013. "Web-Based Alkalinity Calculator." Oregon Water Science Center Website. . http://or.water.usgs.gov/alk/alk.html.

Siebe, C. (1994). "Acumulación y Disponibilidad de Metales Pesados En Suelos Regados Con Aguas Residuales En El Distrito de Riego 03, Tula, Hidalgo, México." Revista Internacional de Contaminación Ambiental 10: 15-21.

Winston, R. B.( 2000). "Graphical User Interface for MODFLOW , Version 4: OpenFile Report 00-315," 34.

Yanin, E.P.( 2007). "Fluorine in the Environment (Prevalence, Behavior, Industrial Pollution)" 4: 2-98. 